\title{
EVALUATION OF GBV-C / HGV VIREMIA IN HIV-INFECTED WOMEN
}

\author{
Synara Araújo SILVA(2), Célia Lima RODRIGUES(1,2), Aléia Faustino CAMPOS(2) \& José Eduardo LEVI(1,2)
}

\begin{abstract}
SUMMARY
The present study aimed at standardizing a real-time quantitative polymerase chain reaction assay to evaluate the presence of GBV-C/HGV RNA. A “TaqMan” assay using primers and probe derived from the 5' NCR region was developed and validated. Two hundred and fifty-three plasma samples from HIV-infected women were tested for GBV-C viremia and antibody against the envelope protein 2. GBV-C RNA was detected in $22.5 \%$ of the patients whereas the antibody was identified in $25.3 \%$ of the cohort. Detection of viral RNA and of antibodies was mutually exclusive. Viral loads showed a mean of 1,777 arbitrary units / $\mathrm{mL}$, being 1.1 and 13,625 arbitrary units / $\mathrm{mL}$ respectively the lowest and highest values measured. We conclude that the real-time quantitative polymerase chain reaction method developed is appropriate for the investigation of GBV-C RNA since it was shown to be highly specific and sensitive, as well as requiring few steps, preventing contamination and providing additional information as to the relative viremia of carriers, a parameter that must be included in studies evaluating the co-factors influencing the clinical outcome of HIV/AIDS.
\end{abstract}

KEYWORDS: GBV-C; Real-Time PCR; Viral load; Anti-HGenv; AIDS.

\section{BACKGROUND}

The GB virus C (GBV-C) or Hepatitis-G Virus (HGV), a member of the Flaviridae family, has a single-stranded positive-sense RNA genome with 9400 nucleotides. Two isolates of this virus were described in concomitance by two different groups working at diagnostic companies trying to identify a putative virus responsible for the remaining cases of non A-H hepatitis ${ }^{12,17}$. Soon after the characterization of both agents, it became evident that they were closely related, but the nomenclature was not unified. However, after extensive research, it became evident that GBV-C is not a hepatotropic virus, since it in fact replicates in lymphocytes ${ }^{5}$. Moreover, no human disease was related to GBV-C, including hepatitis. Therefore, the name Hepatitis G virus is inappropriate, so GBV-C will be used in this report.

GBV-C is prevalent worldwide in healthy populations such as blood donors but also in specific groups of patients like HIV-infected subjects (reviewed $\mathrm{in}^{15}$ ). It is transmitted mainly by sexual contact but also parenterally, which explains the high prevalence found in intravenous drug users and patients submitted to multiple transfusions ${ }^{16}$.

There are refined techniques for detecting GBV-C as a Transcriptase Polymerase Chain Reaction (RT-PCR) for the viral genome. An immunoassay (EIA) detecting antibodies to putative GBV-C envelope protein E2 (anti-E2) has been developed in the past and its use nowadays is restricted to research ${ }^{19}$. The combined use of RT-PCR and EIA has allowed for more comprehensive epidemiological studies of the true status and natural course of GBV-C infection ${ }^{8}$.

Viremia may persist for years, however 60-75\% of immunocompetent persons present spontaneous clearance of GBV-C, and this event usually coincides with the development of antibodies against the GBV-C surface envelope glycoprotein E2. Thus, antibody presence is inversely correlated to RNA viral detection and anti-E2 antibodies serve as a recovery marker in acute and chronic GBV-C infection.

The beneficial effect of the co-infection by the GBV-C/HGV in HIVinfected subjects has been under intense scrutiny and debate over the last few years, after the first demonstration of its protective role by several research groups around the world ${ }^{6,9,21}$. Several studies corroborated these findings ${ }^{23}$ while a few others failed to substantiate them ${ }^{22}$. More recently, a meta-analysis has tried to summarize most of the experimental data regarding this issue and concluded that GBV-C does exert a protective effect in the evolution to AIDS in HIV-infected individuals, independent of several potential confounders ${ }^{26}$. In experimental studies, GBV-C infection of peripheral-blood mononuclear cells resulted in decreased replication of both clinical and laboratory HIV strains that use either CCR5 or CXCR4 as their co-receptor. GBV-C induces HIV inhibitory chemokines and reduces the expression of HIV co-receptor CCR5 in vitro, that could block or reduce the decline of CD4 counts, hence justifying the better prognosis ${ }^{24,25}$.

(1) Virology Lab, Institute of Tropical Medicine, University of São Paulo, São Paulo, SP, Brazil. 
We have been accompanying a cohort of HIV-infected women since 1997, and decided to investigate whether GBV-C status could have influenced survival rates in this cohort. Bearing this in mind, we came to the conclusion that the expected high prevalence of GBV-C RNA carriers among this population could blur the alleged biological effect caused by this virus. Quantification of GBV-C RNA would allow one to observe a gradient of effect and also compare HIV quantitative laboratorial markers like viral load and CD4 counts to GBV-C viremia.

\section{MATERIAL AND METHODS}

1. Samples: We evaluated two hundred and fifty-three plasma samples collected between 1997 and 1999 from HIV-infected women enrolled in studies on Human Papillomavirus and cervical disease ${ }^{10}$. Samples have been stored at $-70{ }^{\circ} \mathrm{C}$ since then, with no thawing. Informed consent was obtained from all participants. This study was approved by the IRB of both recruiting hospitals.

2. RNA extraction and cDNA synthesis: RNA was extracted from $140 \mu \mathrm{L}$ of plasma using the QIAamp Viral RNA mini kit (Qiagen, Hilden, Germany) according to the manufacturer's protocol. RNA was eluted in $60 \mu \mathrm{L}$ of buffer AVE and stored at $-70{ }^{\circ} \mathrm{C}$ or directly submitted to cDNA synthesis. The reverse transcription employed Moloney Murine Leukemia Virus Reverse Transcriptase 2.5 U/ $\mu \mathrm{L}$ (M-MLV RT, Invitrogen, São Paulo, Brazil) and Random Hexamers $2.5 \mu \mathrm{M}$ (Invitrogen, São Paulo, Brazil). The mixture was incubated for 10 minutes at room temperature, then 30 minutes at $37^{\circ} \mathrm{C}$ degrees and finally boiled for five minutes. Five $\mu \mathrm{L}$ of cDNA contains $2.5 \mu \mathrm{L}$ of the extracted RNA which ultimately corresponds to $5.8 \mu \mathrm{L}$ of sera.

3. Measurement of ANTI-E2 antibodies in serum: ANTI-E2 antibodies to GBV-C envelope protein E2 were detected by using the $\mu$ Plate antiHGenv test, Roche Diagnostics (Penzburg, Germany) according to the manufacturer's instructions.

4. Nested-PCR GBV-C: In the first round, $5 \mu \mathrm{L}$ of cDNA, as above, was directly used in a $25 \mu \mathrm{L}$ final volume PCR reaction containing $200 \eta \mathrm{M}$ of the primers G58 (sense; 5'-CAGGGTTGGTAGGTCGTAAATCC-3') and G75 (antisense 5'-CCTATTGGTCAAGAGAGA CAT - 3'), $0.2 \mu \mathrm{M}$ of dNTPs, $2.5 \mathrm{mM}$ of $\mathrm{MgCl}_{2}, 1$ Unit of Taq Platinum (Invitrogen, São Paulo, Brazil), $5 \%$ glycerol and cresol red $0.1 \mu \mathrm{g} / \mu \mathrm{L}$. The first round generated a fragment of $367 \mathrm{bp} .5 \mu \mathrm{Ls}$ of the product of the first round was used as a template for the second round which employed primers G134 (sense 5'-GGTCAYCYTGGTAGCCACTATAGG-3') and G131 antisense (5'-AAGAGAGACATTGWAGGGCGACGT- 3') under the same conditions as in the first round. A fragment of $208 \mathrm{bp}$ is expected for samples containing GBV-C RNA ${ }^{1}$. Cycling parameters were $95^{\circ} \mathrm{C}$ for five minutes, followed by 25 cycles at $94{ }^{\circ} \mathrm{C}$ for 45 seconds, $55^{\circ} \mathrm{C}$ for 45 seconds, $72{ }^{\circ} \mathrm{C}$ for 90 seconds and a final elongation step of 72 ${ }^{\circ} \mathrm{C}$ for five minutes. All reactions were run in an Eppendorf Gradient Mastercycle thermocycler (Eppendorf, Germany).

\section{Quantitative Real Time PCR for GBV-C}

5.1. TaqMan Assay: GBV-C 5 'Non coding region was chosen as a target for primer design since it was shown by several groups to be the most conserved region of GBV-C among different isolates ${ }^{13}$. This region was submitted to the Primer Express software (Applied Biosystems,
Foster City, USA) and several combinations of primers and probes were retrieved. Each possibility was analyzed visually in order to choose the set containing the least nucleotide variability, checked against an alignment of GBV-C 5 NCR sequences. We also valued the primer/probe set where those differences, if unavoidable, would be placed at the first 5' positions of the oligonucleotides, where they are less prone to interfere with the hybridization of the template. Finally, the following assay was produced:

Sense primer RTG1 (5'GTGGTGGATGGGTGATGACA3'); Antisense primer RTG2 (5'GACCCACCTATAGTGGCTACCA3') and probe (5'FAM-CCGGGATTTACGACCTACC-NFQ3') where NFQ stands for "non-fluorescent quencher". ABI provides this assay as a 20X concentrated mix. We added $9 \mu \mathrm{L}$ of cDNA to $10 \mu \mathrm{L}$ of TaqMan Universal PCR Master Mix $2 X$ and $1 \mu \mathrm{L}$ of the 20X TaqMan assay that contains primers at $360 \mu \mathrm{M}$ and the probe at $100 \mu \mathrm{M}$. Cycling conditions were at $95^{\circ} \mathrm{C}$ for 10 minutes, followed by 40 cycles at $95^{\circ} \mathrm{C}$ for 15 seconds, and $60^{\circ} \mathrm{C}$ for one minute.

5.2 Reference material: A $350 \mathrm{~mL}$ plasma bag previously identified as containing high titers of GBV-C RNA was kindly provided by the Hospital Sírio Libanês Blood Bank (São Paulo, Brazil). Serial dilutions of this bag, with normal plasma non-reactive for GBV-C RNA and other markers currently screened in the blood bank, that neat down to 1: 1000000 , were tested in replicates on the real-time assay as above. It was observed that the dilution of $10000 \mathrm{x}$ was detected at a $100 \%$ hit rate so the value of one arbitrary unit was attributed to this dilution and consequently the viral load of the original plasma bag became 10000 arbitrary units / $\mathrm{mL}$ of GBV-C RNA. To generate the standard curve we employed 3 RNA extractions of the neat plasma, plus 1:10, 1:100, 1:1 000, 1:10 000 and 1:100 000 dilutions.

\section{RESULTS}

1. Seroprevalence: Among the two hundred and fifty-three samples analyzed for the presence of anti-E2 antibody, sixty-four were considered reactive, one hundred and forty-six non-reactive and the remaining forty-three indeterminate. Upon repetition, all but five indeterminate were shown to be non-reactive, totaling sixty-nine positive samples. According to the manufacturer recommendation, a confirmatory assay was performed, consisting of the same steps as the regular assay, but omitting the incubation with E2 antigen. Cases remaining reactive in this test are considered false-positives, which was observed in five samples. Thus, the antibody prevalence encountered was $64 / 253=25.3 \%$ ).

2. Nested-PCR: Fifty-seven samples presented the 208 bp amplicon from the GBV-C RNA, in duplicate, corresponding to a prevalence of $57 / 253=22.5 \%$. The concomitant finding of GBV-C RNA and anti-E2 antibody was not observed in any sample. Table 1 summarizes the findings on both methods.

\section{TaqMan assay}

3.1. Sensitivity: Since there is no GBV-C RNA standard available, we used a plasma bag as a reference material. We obtained $\mathrm{Cts}<40$ in all replicates on the 1:10,000 dilution and above. An aliquot of the reference material diluted 10,000x was included in all runs. The run was accepted if the standard curve met the parameters of $\mathrm{R} 2 \geq 0.99$ and a Slope $\leq-3.3$, and the running control presented a Ct of $38 \pm 1$. Figure 1 shows the Standard Curve graphic of a routine run. 
Table 1

Results for the serology and molecular analysis Summary of the combined analysis for the four possible serology/PCR status $(\alpha=$ anti-E2, RNA $\pm=$ PCR positive for both PCR techniques, Real-Time Taman assay and conventional nested-PCR)

\begin{tabular}{lcc}
\hline Serology/PCR Results & $\mathrm{N}$ & $\%$ \\
\hline$\alpha+/$ RNA + & 0 & $0.00 \%$ \\
$\alpha+/$ RNA - & 64 & $25.30 \%$ \\
$\alpha-/$ RNA + & 57 & $22.53 \%$ \\
$\alpha-/$ RNA - & 132 & $52.17 \%$ \\
\hline TOTAL & $\mathbf{2 5 3}$ & $\mathbf{1 0 0 . 0 0 \%}$ \\
\hline
\end{tabular}

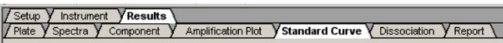

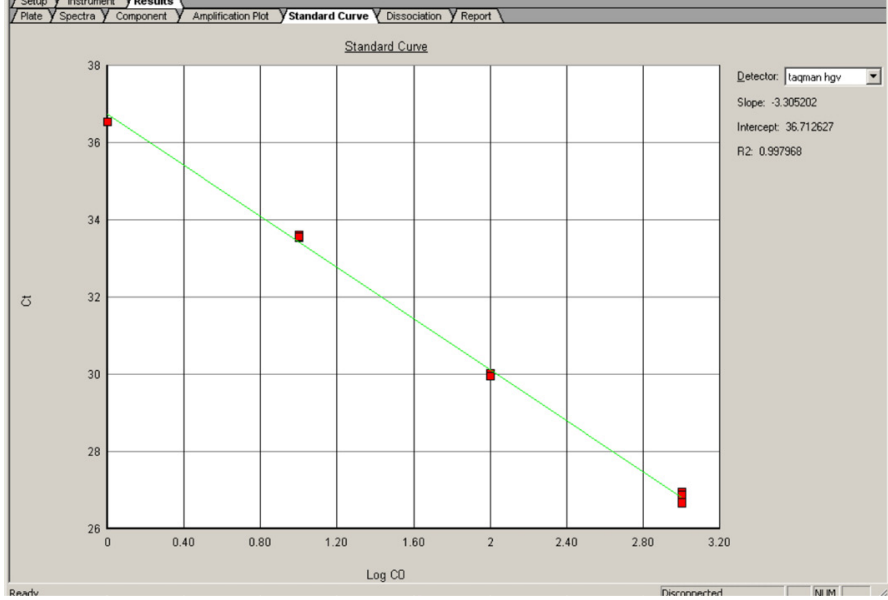

Fig. 1 - Standard curve of GBV-C RNA Real-Time PCR assay. Each point corresponds to triplicates of the reference plasma containing 1, 10, 100 and 1000 arbitrary Units $/ \mathrm{mL}$.

3.2 Specificity: Twenty samples known to contain hepatitis $C$ virus RNA were submitted to this assay and all were shown to be non-reactive. Other samples known to contain RNA from two other flaviviruses, namely dengue and yellow fever, were also submitted to the assay resulting in no amplification. Moreover, experimental samples contained HIV-RNA in a wide range of viral loads, and no cross-reactivity was noticed, as several samples harboring high HIV-RNA loads were non-reactive for this GBV-C quantitative assay.

3.3. Linearity and reproducibility: The assay showed some degree of inhibition in the presence of high amounts of GBV-C RNA, as the amplification from the neat plasma bag resulted in Cts higher than those observed in a 1:5 dilution. This obliged us to re-test all samples displaying Cts below thirty at a 1:5 dilution in addition to the pure plasma. All replicates in the same experiment, but also in different runs beginning from extraction, resulted in variability below one $\mathrm{Ct}$. The same fifty-seven samples reactive for nested-PCR were positive for this assay, resulting in a $100 \%$ concordance for both molecular methods. The highest viral load observed was 13,625 while the lowest was 1.1 arbitrary units/mL.

All samples with a measurable viral load $(\mathrm{N}=57)$ are shown in Table 2 , in addition to the corresponding CD4 cell counts and HIV-1 viral load.
Table 2

GBV-C viral load, CD4 counts and HIV viral load in the 57 patients with detectable GBV-C RNA.

\begin{tabular}{|c|c|c|c|}
\hline ID\# & $\begin{array}{c}\text { GBV-C Viral load } \\
\text { au/mL }\end{array}$ & $\mathrm{CD} 4 / \mu \mathrm{L}$ & $\begin{array}{l}\text { HIV-1 Viral load } \\
\mathrm{cps} / \mathrm{mL}\end{array}$ \\
\hline 254 & 1.1 & 353 & 920 \\
\hline 15 & 2.79 & 341 & 22578 \\
\hline 20 & 2.81 & 361 & 3455 \\
\hline 205 & 4.63 & 146 & 29006 \\
\hline 114 & 5.88 & 230 & 46323 \\
\hline 247 & 9.06 & 219 & 100 \\
\hline 109 & 9.32 & 108 & 47420 \\
\hline 242 & 16.37 & 293 & 5971 \\
\hline 237 & 16.46 & 443 & 2720 \\
\hline 12 & 23.34 & 175 & 49347 \\
\hline 263 & 23.43 & 74 & 942 \\
\hline 62 & 25.16 & 258 & 111173 \\
\hline 45 & 38.32 & 57 & 502 \\
\hline 6 & 41.02 & 168 & 2267 \\
\hline 228 & 43.13 & 272 & 28546 \\
\hline 219 & 45.09 & 38 & 100 \\
\hline 116 & 52.08 & 293 & 481653 \\
\hline 103 & 56.13 & 506 & 378307 \\
\hline 220 & 77.22 & 155 & 4436 \\
\hline 182 & 91.97 & 319 & 10744 \\
\hline 99 & 110.77 & 512 & 130637 \\
\hline 155 & 139.73 & 304 & 4153 \\
\hline 239 & 178.17 & 508 & 13091 \\
\hline 245 & 195.28 & 437 & 13151 \\
\hline 227 & 233.51 & 308 & 42000 \\
\hline 231 & 275.99 & 449 & 7607 \\
\hline 168 & 285.92 & 135 & 100 \\
\hline 105 & 438.7 & 676 & 2404 \\
\hline 236 & 458.93 & 296 & 2467 \\
\hline 185 & 493.88 & 189 & 499 \\
\hline 232 & 576.59 & 305 & 100 \\
\hline 246 & 604.04 & 507 & 100 \\
\hline 235 & 619.8 & 89 & 100 \\
\hline 25 & 637.06 & 317 & 16878 \\
\hline 47 & 812.89 & 365 & 13042 \\
\hline 104 & 820.29 & 228 & 33951 \\
\hline 209 & 853.43 & 300 & 100 \\
\hline 110 & 910.52 & 623 & 19435 \\
\hline 171 & 1221.35 & 500 & 100 \\
\hline 119 & 1221.67 & 487 & 4604 \\
\hline 172 & 1339.76 & 445 & 5840 \\
\hline 88 & 1467.71 & 284 & 810 \\
\hline 212 & 1589.9 & 375 & 858 \\
\hline 30 & 1638.68 & 410 & 40763 \\
\hline 128 & 1710.4 & 379 & 477 \\
\hline 148 & 1895.83 & 108 & 100 \\
\hline 230 & 1916.43 & 208 & 100 \\
\hline 130 & 2336.16 & 314 & 100 \\
\hline 186 & 2769.24 & 254 & 100 \\
\hline 197 & 3899.52 & 332 & 4738 \\
\hline 151 & 3974.57 & 355 & 1411 \\
\hline 64 & 4318.85 & 235 & 100 \\
\hline 213 & 4430.64 & 271 & 100 \\
\hline 66 & 4477.56 & 333 & 56116 \\
\hline 157 & 4511.69 & 655 & 1165 \\
\hline 81 & 12015.04 & 355 & 81986 \\
\hline 70 & 13625.37 & 237 & 4451 \\
\hline
\end{tabular}




\section{DISCUSSION}

The unequivocal beneficial effect that GBV-C infection exerts over the course of HIV/AIDS renewed the interest for laboratorial methods to diagnose and measure this agent on HIV -infected hosts. The prevalence of GBV-C RNA in the HIV-infected population is much higher than that observed in healthy subjects, with greater geographical variations. In Brazil we and others described a prevalence close to $10 \%$ among blood donors $^{2,11}$ while in Europe and North America a prevalence of 1-4\% was verified ${ }^{15}$. In contrast, $14-43 \%$ of HIV-infected subjects harbor the viral RNA. Availability of a serological test (anti-E2) allowed for a more comprehensive view of GBV-C's natural history, permitting the identification of individuals with past exposure to this agent. Moreover, the observation that this antibody would have a protective role and/or is a marker of viral clearance makes it mandatory to evaluate both markers when estimating GBV-C prevalence.

In this study, a similar prevalence of antibody (22.5\%) and RNA $(25.3 \%)$ was observed, resembling what has been described in other groups of individuals with impaired immunity, which may be ascribed to a lower clearance rate, when compared with immunocompetent populations where a rate of viremia to antibody of 1:6 is generally observed ${ }^{23}$.

Another source of variability in the assessment of GBV-C prevalence, besides the population investigated, is the diagnostic method itself. A multicentre study on molecular detection of GBV-C displayed a wide range of sensitivity and specificity achieved among participating laboratories ${ }^{7}$. Primer selection is a key point in the development of successful PCR strategies. Authors comparing genomic regions and different primers among the same target gene in the GBV-C genome concluded that the 5'UTR is the most stable and conserved region and in addition provided a valuable suggestion of "best primers" "1,3,18. The TaqMan assay here described achieved the same sensitivity as a nested-PCR proposed by ANDONOV et al. ${ }^{1}$, in a more convenient and automated format. Moreover, it allows for the quantitation of GBV-C RNA which has not been attempted in other publications. Although we cannot provide an absolute viral load value, aliquots of this standard are available upon request, and may allow our assay to be calibrated against other reference materials. The range of GBV-C viremia was similar to what is observed for other RNA viruses causing chronic infection such as $\mathrm{HIV}$ and $\mathrm{HCV}$. Of course this could reflect the fact that we have analyzed a single sample from each individual, which could hide the fluctuation that may occur over time. One of the few studies that measured GBV-C viremia ${ }^{20}$ found values ranging between 67,000 and $143,000,000$ copies/ $\mathrm{mL}$, a range of $4 \log _{10}$ in the same magnitude as we describe, although the exact correlation between their GBV-C copy and our arbitrary unit cannot be assessed, if one considers one copy $=$ one arbitrary unit our values would be distributed in between 10,000 and 136,250,000 copies/ mL. CASTELAIN et al. also used a TaqMan real-time PCR method to quantify GBV-C genomes in polytrasnsfused children. In contrast to our results, they found on average, much higher titers, what may be a sign of the source of infection ${ }^{4}$.

A convenient, sensitive and reproducible Real-Time PCR method was developed for GBV-C RNA detection and quantitation. The application of this assay has shown its importance as a parameter for the evaluation of factors influencing the outcome of HIV/AIDS disease $\mathrm{e}^{14}$.
RESUMO

\section{Avaliação da viremia por GBV-C/HGV em mulheres infectadas pelo HIV}

Este estudo teve como objetivo o desenvolvimento de método de PCR em Tempo Real para a determinação da viremia do vírus GBV-C. Ensaio baseado em primers e sonda "TaqMan" derivados da região 5' não-codificante deste vírus foi padronizado, validado e aplicado em uma série de 253 amostras de plasma de pacientes HIV+. Além do PCR em tempo real, as amostras foram submetidas a um ensaio imunoenzimático anti-E2 e a um nested-PCR. Das 253 amostras testadas, 64 foram positivas para o anticorpo anti-E2 (25,3\%), enquanto 57 amostras foram concordantemente RNA positivas pelo nested-PCR e PCR em tempo real $(22,5 \%)$, perfazendo um índice total de exposição de $48 \%(25.3+22.5)$. A carga viral teve média de $1.777 \mathrm{UA} / \mathrm{mL}$ (13.625 - 1.1UA/mL). Foi obtida metodologia simples, rápida e de boa sensibilidade e especificidade, permitindo a quantificação do RNA do vírus GBV-C com reprodutibilidade. A metodologia permite a análise simultânea de grande número de amostras, sendo apropriada para estudos clínicos. A prevalência de exposição a este agente na população feminina HIV+ estudada é alta, provavelmente decorrente da via sexual comum de transmissão dos agentes.

\section{ACKNOWLEDGMENTS}

We would like to thank Dr Dietmar Zdunek (Roche, Penzberg, Germany) for his generous gift of anti-HGenv kits.

This study was funded by the Fundação de Amparo a Pesquisa do Estado de São Paulo (FAPESP), grant number 05/01072-9.

\section{DECLARATION OF COMPETING INTERESTS}

The authors declare that they have no competing interests.

\section{REFERENCES}

1. Andonov A, Sauder C, Jacobsen H. Chaudhary R. Comparison of six sets of PCR primers from two different genomic regions for amplification of $\mathrm{GB}$ virus $\mathrm{C} /$ hepatitis $\mathrm{G}$ virus RNA. J Clin Microbiol. 1998:36:286-9.

2. Bassit L, Kleter B, Ribeiro-dos-Santos G, Maertens G, Sabino E, Chamone D, et al. Hepatitis G virus: prevalence and sequence analysis in blood donors of São Paulo, Brazil. Vox Sang. 1998;74:83-7.

3. Bortolin MT, Zanussi S, Tedeschi R, Pratesi C, D’Andrea M, Bidoli E, et al. Evaluation of three molecular biology-based assays for the detection of GB virus C/hepatitis $\mathrm{G}$ virus in clinical specimens. Intervirology. 2004;47:314-20.

4. Castelain S, Francois C, Bonte D, Baron A, Horle B, Morel, V, et al. Epidemiological and quantitative study of GBV-C infection in French polytransfused children. J Med Virol. 2004;73:596-600.

5. Fan X, Xu Y, Solomon H, Ramrakhiani S, Neuschwander-Tetri BA, Di Bisceglie AM. Is hepatitis G/GB virus-C virus hepatotropic? Detection of hepatitis $\mathrm{G} / \mathrm{GB}$ virus-C viral RNA in liver and serum. J Med Virol. 1999;58:160-4

6. Heringlake S, Ockenga J, Tillmann HL, Trautwein C, Meissner D, Stoll M, et al. GB virus $\mathrm{C} /$ hepatitis $\mathrm{G}$ infection: a favorable prognostic factor in human immunodeficiency virus-infected patients? J Infect Dis. 1998;177:1723-6. 
7. Lefrère JJ, Lerable J, Mariotti M, Bogard M, Thibault V, Frangeul L, et al. Lessons from a multicentre study of the detectability of viral genomes based on a two-round quality control of GB virus C (GBV-C)/hepatitis G virus (HGV) polymerase chain reaction assay. J Virol Methods. 2000;85:117-24

8. Lefrère JJ, Loiseau P, Maury J, Lasserre J, Mariotti M, Ravera N, et al. Natural history of GBV-C/hepatitis G virus infection through the follow-up of GBV-C/hepatitis G virus-infected blood donors and recipients studied by RNA polymerase chain reaction and anti-E2 serology. Blood. 1997;90:3776-80.

9. Lefrère JJ, Roudot-Thoraval F, Morand-Joubert L, Petit JC, Lerable J, Thauvin M, et al. Carriage of GB virus $\mathrm{C}$ /hepatitis $\mathrm{G}$ virus RNA is associated with a slower immunologic, virologic, and clinical progression of human immunodeficiency virus disease in coinfected persons. J Infect Dis. 1999;179:783-9.

10. Levi JE, Fernandes S, Tateno AF, Motta E, Lima LP, Eluf-Neto J, et al. Presence of multiple human papillomavirus types in cervical samples from HIV-infected women. Gynecol Oncol. 2004;92:225-31.

11. Levi JE, Contri DG, Lima LP, Takaoka DT, Garrini RH, Santos W, et al. High prevalence of $\mathrm{GB}$ virus $\mathrm{C} /$ hepatitis $\mathrm{G}$ virus RNA among Brazilian blood donors. Rev Inst Med Trop Sao Paulo. 2003;45:75-8.

12. Linnen J, Wages J Jr, Zhang-Keck ZY, Fry KE, Krawczynski KZ, Alter H, et al. Molecular cloning and disease association of hepatitis $\mathrm{G}$ virus: a transfusion-transmissible agent. Science. 1996;271:505-8.

13. Linnen JM, Fung K, Fry KE, Mizokami M, Ohba K, Wages JM Jr, et al. Sequence variation and phylogenetic analysis of the 5 ' terminus of hepatitis $\mathrm{G}$ virus. J Viral Hepat. 1997;4:293-302.

14. Maidana-Giret MT, Silva TM, Sauer MM, Tomiyama H, Levi JE, Bassichetto KC, et al. GB virus type $\mathrm{C}$ infection modulates T-cell activation independently of HIV-1 viral load. AIDS. 2009;23:2277-87.

15. Mohr EL, Stapleton JT. GB virus type C interactions with HIV: the role of envelope glycoproteins. J Viral Hepat. 2009;16:757-68.

16. Reshetnyak VI, Karlovich TI, Ilchenko LU. Hepatitis G virus. World J Gastroenterol. 2008;14:4725-34.

17. Simmons JN, Leary TP, Dawson GJ, Pilot-Matias AS, Muerhoff AS, Schlauder GG, et al. Isolation of novel virus-like sequences associated with human hepatitis. Nat Med. 1995;1:564-9.
18. Souza IE, Allen JB, Xiang J, Klinzman D, Diaz R, Zhang S, et al. Effect of primer selection on estimates of $\mathrm{GB}$ virus $\mathrm{C}(\mathrm{GBV}-\mathrm{C})$ prevalence and response to antiretroviral therapy for optimal testing for GBV-C viremia. J Clin Microbiol. 2006;44:3105-13.

19. Tacke M, Kiyosawa K, Stark K, Schlueter V, Ofenloch-Haehnle B, Hess G, et al. Detection of antibodies to a putative hepatitis G virus envelope protein. Lancet. 1997:349:318 20. Erratum in: Lancet. 1997;349:736.

20. Tillmann HL, Heiken H, Knapik-Botor A, Heringlake S, Ockenga J, Wilber JC, et al Infection with $\mathrm{GB}$ virus $\mathrm{C}$ and reduced mortality among HIV-infected patients. $\mathrm{N}$ Engl J Med. 2001;345:715-24.

21. Toyoda H, Fukuda Y, Hayakawa T, Takamatsu J, Saito, H. Effect of GB virus C/hepatitis $\mathrm{G}$ virus co-infection on the course of HIV infection in hemophilia patients in Japan. J Acquir Immune Defic Syndr Hum Retrovirol. 1998;17:209-13.

22. Van der Bij AK, Kloosterboer N, Prins M, Boeser-Nunnink B, Geskus RB, Lange JM, et al. GB virus $\mathrm{C}$ coinfection and HIV-1 disease progression: The Amsterdam Cohor Study. J Infect Dis. 2005;191:678-85.

23. Williams CF, Klinzman D, Yamashita TE, Xiang J, Polgreen PM, Rinaldo C, et al. Persistent GB virus $\mathrm{C}$ infection and survival in HIV-infected men. N Engl J Med. 2004;350:981-90.

24. Xiang J, George SL, Wünschmann S, Chang Q, Klinzman D, Stapleton JT. Inhibition of HIV-1 replication by GB virus $C$ infection through increases in RANTES, MIP- $1 \alpha$, MIP-1ß, and SDF-1. Lancet. 2004;363:2040-6.

25. Xiang J, Wünschmann S, Diekema DJ, Klinzman D, Patrick KD, George SL, et al. Effect of coinfection with GB virus $\mathrm{C}$ on survival among patients with HIV infection. N Engl J Med. 2001;345:707-14.

26. Zhang W, Chaloner K, Tillmann HL, Williams CF, Stapleton JT. Effect of early and late GB virus $\mathrm{C}$ viraemia on survival of HIV-infected individuals: a meta-analysis. HIV Medicine $2006 ; 7: 173-80$

Received: 18 January 2011

Accepted: 21 November 2011 